\title{
Habitat preference of large grey mongooses Herpestes ichneumon in Spain
}

\author{
Francisco PALOMARES and Miguel DELIBES
}

\begin{abstract}
Palomares F. and Delibes M. 1990. Habitat preference of large grey mongooses Herpestes ichneumon in Spain. Acta theriol. 35: 1-6.

By using radio-tracking to analyse habitat preferences of grey mongooses Herpestes ichneumon (Linnaeus, 1758) at the Doñana Biological Reserve, we have distinguished eight habitat types in order of ground cover and vegetation density. Three mongooses (two adult and a young female) were radiotracked on foot at close range by twenty-eight 24-hour periods between October ' 85 and April ' 86 , as that the habitat occupied at any moment was known. We compared the availability and use of each habitat type by Jacobs index (D). During activity, the mongooses spent most of their time in brambles (BR), $35 \%$ of time, and xerophytic scrubland (XS), $27 \%$ of time, the habitats with most vegetation and prey density, followed by rushes (RU), hygrophytic scrubland (HS), marshes (MA) and dune hollows (DH). There was no appreciable use of habitat without cover as bare sand dunes (BD) and grassland and bracken (GB). The running speed of mongooses on each habitat type is related to prey type. The nocturnal resting place was in BR $(81.0 \%)$ principally, followed by XS, HS, $\mathrm{DH}$, and RU $(\mathrm{N}=58)$. The short daytime resting periods or "siestas" were in BR $(65 \%$ of the time), followed by XS, HS, DH and RU. Statistical differences between activity, resting habitat use and habitat availability were detected.
\end{abstract}

Estación Biológica de Doñana, CSIC. Apdo. 1056, 41080 Sevilla, Spain

Key words: habitat preference, Herpestes ichneumon, Spain

\section{Introduction}

Habitat use is an important aspect of the biology of any species, the knowledge of which is specially useful for conservation and management purposes. For carnivores, which are usually scarce and shy, studies of habitat preference were largely anecdotal before the widespread use of radiotelemetry, which permitted the location and, if necessary, sighting of an animal at a distance. We have used this technique to investigate the preferences in habitat use of the ichneumon in SW Spain.

The ichneumon or large grey mongoose Herpestes ichneumon (Linnaeus, 1758) is the only mongoose living in Europe, where its range is restricted to SW Iberia (Delibes 1982). The species also occupies most of Africa and the Middle East (Corbet 1984). On the basis of casual observations and captures, it has been associated with areas of high vegetal cover (Delibes 1982, Ben-Yaacov and Yom-Tow 1983, Stuart 1983), but there are no previous studies quantifying habitat use and considering different activities.

The aims of this paper are: (1) to describe habitat preference of active (hunting and running) mongooses, by comparing the actual time spent in each habitat with the time expected from habitat availability, (2) to analyse the running speed of mongooses in 
each habitat, as an approach to distinguish between different habitat-related behaviours, (3) to describe resting sites and resting habitat preference of mongooses, both at night (they are diurnal) and in the short daytime resting periods ("siestas").

\section{Study area}

The study was carried out in the Donana Biological Reserve, on the right bank of the river Guadalquivir near its mouth, in SW Spain (approx. $37^{\circ} \mathrm{N}, 6^{0} 30 \mathrm{~W}$ ). The climate is subhumid mediterranean, characterized by dry, hot summers and mild, wet winters. The three main biotopes within the area are: sand dunes with pine forests in the dune hollows, scrubland and marshland. These make up a vegetation mosaic which has been described in several papers (Allier et al. 1974, Rivas-Martínez et al. 1980). We selected an area of about 15 square kilometres in the Reserve, and distinguished eight habitat types. A brief description, in order of decreasing ground cover and vegetation density, is as follows (for more details see descriptions by Rivas-Martinez et al. 1980):

1. Brambles (BR): formed principally by Rubus sp. with which heathers, gorses Ulex sp., rushes and bracken Pteridium sp. can be associated (Lonicero hispaniae - Rubetum ulmifolii association). It is a very dense habitat of high cover.

2. Hygrophytic scrubland (HS): this consists of very dense clumps of heathers Erica sp. up to $3 \mathrm{~m}$ high (Erico scoparidae Ullicetum australis and Erico ciliaris - Ullicetum (minaris) lusitanici associations).

3. Xerophytic scrubland (XS): this mainly consists of Halimium sp. There are also associated Cistus sp., gorses Ulex sp. and rosemary Rosmarinus officinalis, (Halimio halimifolii-Stauracanthetum genistoidis association). The heights reach $1.5 \mathrm{~m}$ in some places and the plants offer medium cover.

4. Rushes (RU): associations of rushes Juncus sp. of variable height and density (Junco emmauelis

Eleocharidetum nuulticaulis and Galio palustri-Juncetum maritimi associations).

5. Dune hollows (DH): colonized by pines Pinus pinea and varied scrub of rushes Halimium sp. and heathers of variable density. A mixture of the above described associations.

6. Marshes (MA): a biotope flooded in the wet season and without water in the dry one. Dominated by sea club rush Scirpus sp. (Scirpetum maritimi association).

7. Grassland and Bracken (GB): grass and bracken pastureland (Trifolio resupinati-Caricetum chaetophyllae association).

8. Bare sand Dunes (BD): loose sand of the dune system with scarcely any vegetation.

Proportions of above mentioned habitats were $5.1,16.1,32.8,8.6,7.3,25.3,3.0$, and $1.8 \%$ respectively.

\section{Methods}

Between September 1985 and April 1986 four mongooses: two adult females (H5 and H6) and two subadult or young females $(\mathrm{Hl}$ and $\mathrm{H} 4)$ were fitted with radio-collars working on the $151 \mathrm{MHz}$ range and provided with tip switches sensors. The animals were tracked for periods of $50(\mathrm{H} 5), 128(\mathrm{H} 6), 17(\mathrm{H} 4)$ and $210(\mathrm{HI})$ days.

Habitat use, nocturnal resting place, and running speed, were estimated from 28 independent 24-hour periods of continuous tracking of three animals $(\mathrm{Hl}, \mathrm{H} 5$ and $\mathrm{H} 6)$. $\mathrm{H} 4$ was a female cub of $\mathrm{H} 6$ and during the tracking period showed a similar use of habitat as its mother. Radio signals were used to locate the animals, which were tracked on foot at close distance, which allowed us to know the habitat occupied at any moment. Resting was detected through the tip switch sensor.

We noted the time spent by each active individual within each habitat type and compared it with the availability (percentage) of each habitat in the minimum convex polygon (Macdonald et al., 1980) used by this individual. Results of the twenty-eight 24 -hour periods were pooled. In the analysis we have not 
included isolated locations obtained over the tracking periods by triangulation, as there is an error associated with this method (Tester and Siniff 1965, Heenze and Tester 1967), which in a mosaic environment could produce serious biases (Saltz and White 1990).

Mongooses are diurnal in the study area, resting for 16 hours on the average each night and 2 more hours of "siesta" by daytime (Palomares 1986). Thus, for nocturnal resting we detected habitat preference from the number of nights on each habitat type, while habitat preference for daytime siestas was derived from time spent in them.

Running speed was estimated from the distance covered in half-an-hour periods. Habitat preferences were estimated by the Jacobs index (Jacobs 1974) which varies from +1 (maximun preference) to -1 (minimum preference). Statistical differences between availability and use of habitats were estimated by chi-square tests and Tukey test. Average time spent and running speed in each habitat were compared with $t$-tests.

\section{Results and discussion \\ Hunting and travelling habitat}

The mongooses spent most of their active time in BR $(35 \%)$, followed by XS $(27 \%)$, RU (15\%), HS (12\%), MA (6\%) and DH (4\%) (Table 1). There was no appreciable use of BD and GB, which they only used to cross from one habitat type to

Table 1. Percent of use (PU) of each habitat type for hunting, "siestas", and resting, index of Jacobs $(D)$ to estimate habitat selection, and average $(\bar{x})$ running speed on each habitat. The significance of Tukey test

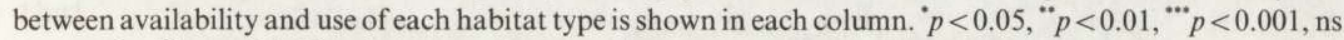
$=$ not significant, ${ }^{a}$ half an hour-periods.

\begin{tabular}{|c|c|c|c|c|c|c|c|c|}
\hline \multirow[t]{2}{*}{ Habitat type } & \multicolumn{2}{|c|}{$\begin{array}{c}\begin{array}{c}\text { Hunting } \\
\mathrm{n}=9941 \mathrm{~min} .\end{array} \\
\end{array}$} & \multicolumn{2}{|c|}{$\begin{aligned} & \text { Siestas } \\
& \mathrm{n}= 3148 \mathrm{~min} . \\
&\end{aligned}$} & \multicolumn{2}{|c|}{$\begin{array}{l}\text { Night resting } \\
\mathrm{n}=58 \text { nights }\end{array}$} & \multicolumn{2}{|c|}{$\begin{array}{c}\text { Running speed } \\
(\%)\end{array}$} \\
\hline & PU & $D$ & $\mathrm{PU}$ & $D$ & $\mathrm{PU}$ & $D$ & $\bar{x}$ & $\mathrm{n}^{\mathrm{a}}$ \\
\hline Xerophytic scrubland (XS) & $26.8^{* *}$ & -0.12 & $8.8^{\cdots}$ & -0.61 & $1.7^{* *}$ & -0.90 & 481,6 & 69 \\
\hline Hygrophytic scrubland (HS) & $13.0^{\mathrm{ns}}$ & -0.17 & $11.7^{* *}$ & -0.15 & $12.1^{\cdots}$ & -0.15 & 231,6 & 35 \\
\hline Brambles (BR) & 35.6 & 0.78 & $65.9^{* \cdots}$ & 0.90 & $81.0^{* . *}$ & 0.93 & 250,2 & 144 \\
\hline Rushes (RU) & $14.7^{* * *}$ & 0.26 & $5.7^{*}$ & 0.21 & $0.0^{* * *}$ & -1.00 & 373,6 & 44 \\
\hline Marshes (MA) & $6.1^{\cdots}$ & -0.67 & $0.0^{\cdots}$ & -1.00 & $1.7^{* *}$ & -0.87 & 597,5 & 20 \\
\hline Dune hollows $(\mathrm{DH})$ & $3.6^{* *}$ & -0.28 & $7.8^{\text {ns }}$ & 0.07 & $3.4^{\cdots *}$ & -0.41 & 378,0 & 13 \\
\hline Grassland and bracken (GB) & $0.0^{\ldots}$ & -1.00 & $0.0^{* * *}$ & -1.00 & $0.0^{* \cdots}$ & -1.00 & - & - \\
\hline Bare sand dunes (BD) & $0.0^{* * *}$ & -1.00 & $0.0^{* * *}$ & -1.00 & $0.0^{* *}$ & -1.00 & - & - \\
\hline
\end{tabular}

Table 2. Statistical significance of the comparison by the Student t-test of the average time (AT) spent in each habitat during activity and the average running speed $(\mathrm{S})$ on each habitat. $p<0.05$, ${ }^{*} p<0.01, \cdots p<0.001, \mathrm{~ns}=$ not significant.

\begin{tabular}{lcccccc}
\hline \multirow{2}{*}{ Time (AT) } & XS & HS & BR & RU & MA & DH \\
\hline Xerophytic scrubland (XS) & - & $* * *$ & $* * *$ & ns & ns & ns \\
Hygrophytic scrubland (HS) & $*$ & - & ns & $* *$ & $* * *$ & ns \\
Brambles (BR) & ns & $* * *$ & $-* *$ & $* * *$ & $* * *$ & ns \\
Rushes (RU) & $* *$ & ns & $* * *$ & - & $*$ & ns \\
Marshes (MA) & $* * *$ & ns & $* * *$ & ns & - & ns \\
Dune hollows (DH) & $* * *$ & $*$ & $* * *$ & $* *$ & ns & - \\
\hline
\end{tabular}


another and usually at a great speed. Time spent on BR and XS was statistically greater than that in any other of the habitat types. The differences were also significant between time spent in RU and DH, and DH and HS (Table 2).

Habitat types were not used in proportion to their availability (Table 1). There are two preferred habitat types with positive Jacobs' index: BR $(D=0.78 ; q=23.5, \mathrm{p}<$ $0.001)$ and $\mathrm{RU}(D=0.26 ; q=5.4, \mathrm{p}<0.001)$. The other habitats were rejected (negative Jacobs' index), especially among those used now and then, MA ( $D=-0.67 ; q=16, \mathrm{p}<$ 0.001) (Table 1).

Apparently, mongooses spend more time searching in habitats richer in prey. In the study season and in the study area, ichneumons mainly feed on small mammals (mice and shrews), rabbits Oryctolagus cuniculus and carrion, in that order of importance, although reptiles, birds, amphibians and some insects are also taken (Palomares 1986). BR and HS support the higher diversity and abundance of small mammals in the area, but Mus spretus which is an important species in the diet of the mongooses, also reaches high densities in RU (Kufner 1986, Camacho and Moreno 1989). Mongooses mostly take rabbits in their burrows (F. Palomares and M. Delibes unpubl.), which are found in greater abundance in XS. Finally, carrion, consisting mostly of Sus scrofa, is mainly found in areas of rushes around the marshes. In the study season mongooses avoid flooded marshes (MA), where introduced American crayfish, a potential prey, breed.

\section{Habitat-related running speed}

The speed of mongooses' running on each habitat type is shown in Table 1. They move more slowly in HS and BR, and more rapidly in MA and XS. Average speed in HS and BR differs statistically from that in the remaining habitats except DH. Average speeds in RU and MA also differ (Table 2).

A relationship seems to exist between running speed in each habitat and the prey species obtained in it. Mongooses move slowly in BR and HS, where the capture of small and evenly distributed mice and shrews requires a major searching effort and accordingly a low speed. On the other hand, the burrows of rabbits are found in fixed and predictable sites, primarily in XS, and mongooses move faster in this type of habitat, with direct and rapid movements towards the rabbit warrens. In RU, where mongooses principally search for carrion and mice Mus spretus searching effort and speed are intermediate: carrion is a large static food resource easily detected, while mice detection requires a greater searching time. Finally, in DH, a habitat containing very diverse scrub, the speed of movement was also intermediate.

\section{Resting habitat}

BR was chosen to rest $81.0 \%$ of the nights considered ( $n=58)$, followed by HS (12.1\%), DH (3.4\%), XS (1.7\%) and RU (1.7\%) (Table 1). The observed frequencies of use were statistically different from those expected from habitat availability $\left(\chi^{2}=\right.$ $76.087, p<0.001)$ (Table 1). The only habitat preferred was BR $(D=0.93, q=51.1$, 
$p<0.001)$, the other being rejected with high negative values of $D$, except in the case of HS $(D=-0.15 ; q=3.3, p<0.05)$ (Table 1$)$.

We have tried to determine the precise resting site on each occasion. Most of the times $(70.7 \%)$ sites were inside bramble thickets, followed by underground burrows $(17.2 \%)$, heather thickets $(10.4 \%)$ and flattened rushes in the open air at marshes $(1.7 \%)$. Probably, the importance of underground burrows to rest was underestimated, as very often we were unable to reach the exact location of the resting site, being hidden by brush or bramble thickets (for instance, Beltrán et al. 1985, recovered a dead individual inside a rabbit warren under brambles). Presence of underground burrows used by mongooses was detected in BR, XS, DH and the edges of HS. These burrows were not built by the mongooses themselves, as rabbit warrens and badgers setts (sometimes occupied by badgers Meles meles) were used.

Most of the time devoted to "siestas" was spent in BR ( $65.9 \%)$, followed by HS (11.7\%), XS (8.8\%), DH (7.8\%) and RU (5.7\%) (Table 1). The different habitat types were not used according to their availability (Table 1). The preferred habitat for "siestas" was BR $(D=0.90, q=41.2, p<0.001)$, followed by RU $(D=0.21, q=3.3$, $p<0.05)$ and $\mathrm{DH}(D=0.07, q=0.1$, ns). The remaining ones were rejected with high $D$ values, except HS $(D=-0.15, q=3.7, p<0.01)$ (Table 1). Average time spent in BR differs statistically from that spent in other habitats $(t=4.489,4.495,4.939$ for XS, HS and RU respectively; $p<0.001$ ). On XS and DH we confirmed on most occasions that "siestas" occurred in underground rabbit warrens.

\section{Conclusions}

Our short distance radio-tracking of mongooses during activity and resting enabled the patterns of habitat use to be distinguished, avoiding the common bias associated with the triangulation technique (for commentaries see White and Garrott 1986, Kufeld et al. 1987, Saltz and White 1990).

Large grey mongooses in general preferred areas with high cover and protection. Overall, the quantitative results from the present study matched with what could be predicted from anecdotical observations (Delibes 1982, Ben-Yaacov and Yom-Tow 1983, Stuart 1983). The data demonstrate that a greater diversity of habitat types was used for hunting and running activities $(B=2.13$, diversity index, Levins 1968$)$ than for resting, as well as both at night $(B=0.69)$ and during the "siestas" $(B=1.5)$ in the middle of the day. In the resting period much more concentration on areas offering greater protection (principally BR and to some extent HS) was detected. Prey availability seems to be the more important factor affecting hunting habitat preferences, while the presence of safe sheltering (abundant vegetal cover and rabbit warrens) would condition the selection of resting habitat.

Overall, mongooses showed preferences in their use of habitat, especially for resting. Dense patches of vegetation with brambles and underground burrows play an important role in their activity, as is proved by BR, representing only $5 \%$ of the 
available habitat. This was used to rest $80 \%$ of the nights and $66 \%$ and $36 \%$ of the time devoted to "siestas" and to hunt respectively. For hunting, mongooses show a more diverse pattern of habitat use, but they practically never utilize bare open areas.

Acknowledgements: The research was supported by DGICYT (project PB87-0405). One of the authors (FP) has a grant of PFPI of Ministerio de Educación y Ciencia. We thank two anonymous referees for reviewing the manuscript and N. Bustamante for reviewing the English.

\section{References}

Allier C., González Bernaldez F. and Ramírez Díaz L. 1974. Mapa ecológico de la Reserva Biológica de Doñana. CSIC, Estación Biológica de Doñana, Sevilla.

Beltrán J. F., Delibes M. and Ibañez C. 1985. Immobilization and marking of the Egyptian mongoose, Herpestes ichneumon (L.), in Spain. Z. Säugetierk. 50: 243-244.

Ben-Yaacov R. and Yom-Tow R. 1983. On the biology of the Egyptian mongoose, Herpestes ichneumon, in Israel. Z. Säugetierk. 48: 34-45.

Camacho J. and Moreno S. 1989. Distribución espacial de micromamíferos en el Parque Nacional de Doñana. Doñana Acta Vert. 16: 239-245.

Corbet G. B. 1984. The mammals of the Palearctic Region: a taxonomic review. British Museum (Natural History). Cornell Univ. Press, London: 1-314.

Delibes M. 1982. Notas sobre la distribución pasada y actual del meloncillo Herpestes ichneumon (L.) en la Península Ibérica. Doñana. Acta Vert. 9: $341-352$.

Heenze K. L. and Tester J. R. 1967. Evaluation of radio-tracking by triangulation with special reference to deer movements. J. Wildl. Manage. 31: 124-141.

Jacobs J. 1974. Quantitative measurements of food selection. A modification of the forage ratio and Ivlev's Electivity Index. Oecologia (Berl.) 14: 413-417.

Kufeld R. C., Bowden D. C. and Siperek J. M., Jr 1987. Evaluation of a telemetry system for measuring habitat usage in mountainous terrain. Northwest Science 61: 249-256.

Kufner M. B. 1986. Tamaño, actividad, densidad relativa y preferencias de hábitat de los pequeños y medianos mamíferos de Doñana, como factores condicionantes de su tasa de predación. Ph. D. thesis, Univ. Autonoma de Madrid. Fac. de Biología.

Levins R. 1968. Evolution in changing environments. Princeton, New Jersey. University Press.

Macdonald D. W., Ball F. G. and Hough N. G. 1980. The evaluation of home range size and configuration using radio tracking data. [In: A handbook on biotelemetry and radio tracking. C. J. Amlaner and D. W. Macdonald, eds]. Pergamon Press, Oxford: 405-424.

Palomares F. 1986. Ecología de la gineta y el meloncillo en el Parque Nacional de Doñana. M. Sc. thesis, Fac. de Ciencias. Univ. de Granada: 1-186

Rivas-Martinez S., Costa M., Castroviejo S. and Valdes E. 1980. Vegetación de Doñana (Huelva, España). Lazaroa 2: 1- 189.

Saltz D. and White G. C. 1990. Comparing different measures of the error involved in radio-telemetry location. J. Wildl. Manage. 54: 169-174.

Stuart C. T. 1983. Food of the large grey mongoose Herpestes ichneumon in the south-west Cape Province. S. Afr. J. Zool. 18: $401-403$.

Tester J. R. and Siniff D. B. 1965. Aspect of animal movement and home range data obtained by telemetry. Thirtieth North American Wildlife Conference 30: 379-392.

White G. C. and Garrott R. A. 1986. Effects of biotelemetry triangulation error on detecting habitat selection. J. Wildl. Manage. 50: 509-513.

Received 9 November 1989, accepted 22 July 1990. 